\title{
48. DATA REPORT: GEOCHEMICAL WELL LOGS THROUGH CENOZOIC SEDIMENTS FROM SITES 805 AND $806^{1}$
}

\author{
Elizabeth Lewis Pratson, ${ }^{2}$ Mitchell Lyle,$^{2}$ and Jennifer Tivy ${ }^{2}$
}

\begin{abstract}
Geochemical well logs were obtained in sediment at Sites 805 and 806 of Ocean Drilling Program Leg 130. Corrections have been applied to the logs to account for variations in bore-hole size, drilling-fluid composition, and drill-pipe attenuation. Oxide and calcium carbonate weight percentages were calculated from the logs and are compared with available carbonate measurements from core. $\mathrm{Log}$-derived $\mathrm{CaCO}_{3}$ values from Hole $805 \mathrm{C}$, though lower than shipboard $\mathrm{CaCO}_{3}$ core measurements, show a similar variation in character. In Hole $806 \mathrm{~B}, \log$ and shipboard $\mathrm{CaCO}_{3}$ sample values have a similar mean and variance. The $\mathrm{CaCO}_{3}$ high-resolution sample values from Hole $806 \mathrm{~B}$, however, have a similar mean but a lower variance than the $\mathrm{CaCO}_{3} \log$. It is probable that discrepancies result from gamma-ray spectrometry tool malfunctions experienced throughout the logging operations of this leg as well as from chlorine-induced interference in the calcium yield. Because the amplitude of $\mathrm{CaCO}_{3}$ variations was extremely low (standard deviation of 1.38 on high-resolution samples), the tool, which has a sensitivity of roughly $2 \%$ for Ca, probably would not have been able to detect these variations, even if the tool had been working properly.
\end{abstract}

\section{INTRODUCTION}

Leg 130 of the Ocean Drilling Program (ODP), which took place on the northeastern margin of the Ontong Java Plateau, was targeted at drilling a transect of sites that would provide a record of carbonate deposition in the western equatorial Pacific. Five sites were drilled on Leg 130: four sites (Sites 803-806) down the northeastern flank of the plateau produced a complete Neogene sediment transect; one basement objective site (Site 807 ) was drilled to investigate tectonism of the Ontong Java Plateau (Fig. 1).

Two of the drilled sites were logged with the geochemical tool string (Sites 805 and 806). The geochemical tool string measures the major elements of a formation at intervals of $0.1524 \mathrm{~m}$. The geochemical measurements provide continuous, in-situ measurements, unaffected by incomplete core recovery or core expansion, problems that core-based studies often encounter.

Problems with the gamma-ray spectrometry tool (GST) within the geochemical tool string were experienced throughout Leg 130. When the tool was brought back to shore, a bad resistor was discovered, and several of the board connections had to be adjusted and resoldered. The amplitude and frequency of the zinc calibration peaks also required readjustment. The GST did not record any data at Site 803 , because it was found to be out of tolerance. No logging was performed at Site 804. At Sites 805 and 806, the tool recorded data with problems. The GST failed the deck test at Site 807 and was not run at this site. Working in conjunction with the SchlumbergerDoll Research Center to process the geochemical data from this leg, we have extracted all possible information from the GST spectra recorded at Sites 805 and 806.

This report describes the hole conditions and logging operations at each site, presents the basic principles of the geochemical tool string, explains the data processing techniques, and compares the processed natural gamma-ray and oxide/calcium carbonate concentrations estimated from the logs to the available core measurements.

\footnotetext{
'Berger, W.H., Kroenke, L.W., Mayer, L.A., et al., 1993. Proc. ODP, Sci. Results, 130: College Station, TX (Ocean Drilling Program).

${ }^{2}$ Borehole Research Group, Lamont-Doherty Geological Observatory, Columbia University, Palisades, NY 10964, U.S.A.
}

\section{DATA ACQUISITION}

\section{Site 805}

The objective for drilling at Site 805 was to recover an intermediate section of the Neogene sediments within the leg's depth transect. Hole $805 \mathrm{~A}$ was drilled with the advanced hydraulic piston corer (APC) to 50.3 mbsf with $103 \%$ recovery. Hole $805 \mathrm{~B}$ was drilled with the APC to 263.2 mbsf with $103 \%$ recovery and then with the extended core barrel (XCB) to $473.3 \mathrm{mbsf}$ with $83 \%$ recovery. Hole $805 \mathrm{C}$ was drilled with the APC to 235.8 mbsf with $100 \%$ recovery and with the XCB to 611 mbsf with $80 \%$ recovery. Hole $805 \mathrm{C}$ was conditioned and cleaned by pulling pipe, followed by a mud sweep; the pipe was then set to $116.3 \mathrm{mbsf}$ to prepare for logging (Shipboard Scientific Party, 1991a).

Two logging passes were completed at Hole $805 \mathrm{C}$. The first logging tool string run in the hole consisted of a sonic velocity tool, a resistivity tool, and a natural gamma-ray tool. This tool string functioned smoothly throughout the recording process. The second tool string, a geochemical string with a lithodensity tool attached, consisted of the gamma-ray spectrometry, aluminum clay, natural gamma-ray, lithodensity, and Lamont temperature tool. This tool string, lowered to $609 \mathrm{mbsf}$, logged up to $331 \mathrm{mbsf}$, where it was reported that the GST was out of tolerance. The tool was lowered to $444 \mathrm{mbsf}$, and a repeat run was attempted; however, the GST was still out of tolerance.

\section{Site 806}

Site 806 represents the shallow portion of the Neogene sediment transect. Hole $806 \mathrm{~A}$ was drilled with the APC to $83.7 \mathrm{mbsf}$ with $103 \%$ recovery. Hole $806 \mathrm{~B}$ was drilled with the APC to $320 \mathrm{mbsf}$ with $105 \%$ recovery and then drilled with the XCB to 743.1 mbsf with $78.3 \%$ recovery. Pipe was then pulled up to $92 \mathrm{mbsf}$, and a high-viscosity mud sweep was made to clean the hole for logging.

Two logging runs with identical configurations to those made in Hole $805 \mathrm{C}$ were completed in Hole $806 \mathrm{~B}$. The first geophysical tool string was run successfully from 741 to 90 mbsf. On the geochemical combination tool string, the GST again experienced difficulties. The tool, lowered to $740 \mathrm{mbsf}$, malfunctioned at $703 \mathrm{mbsf}$. The tool was then lowered to the bottom of the hole and appeared to run smoothly until 486.5 mbsf, at which depth the GST lost resolution. The tool string was lowered to $496 \mathrm{mbsf}$ in an unsuccessful attempt to recali- 


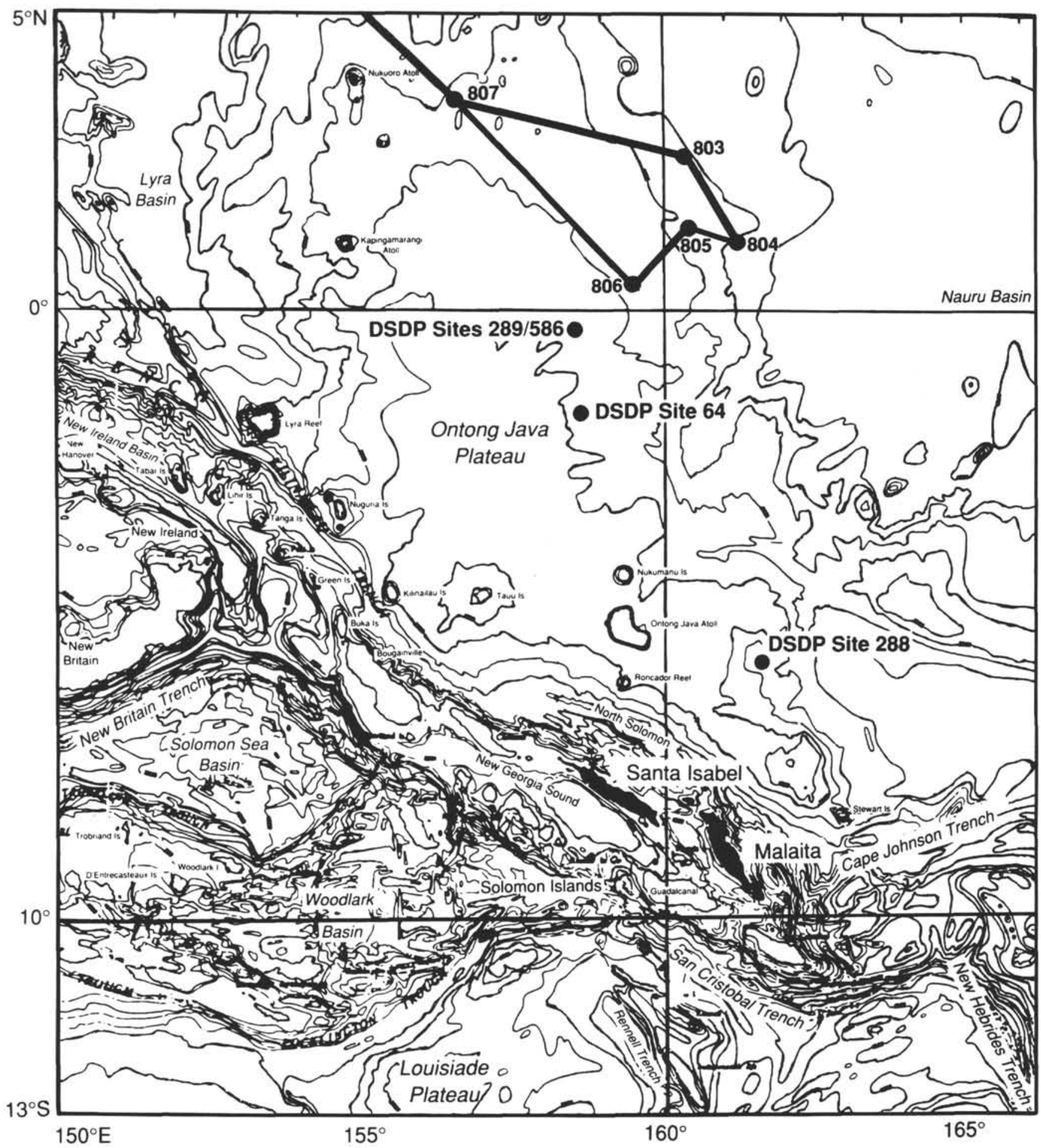

Figure 1. Location of ODP Leg 130 Sites 803-807 and the sites of DSDP Legs 7 (Site 64), 30 (Sites 288 and 289), and 89 (Site 586) in the Ontong Java Plateau (after Kroenke et al., 1983).

brate the GST. The GST was shut down thereafter, and the remainder of the hole was logged with the other tools on the string.

\section{GEOCHEMICAL TOOL STRING}

The geochemical logging tool string (GLT) consists of four logging tools: the natural gamma-ray tool (NGT), the compensated neutron tool (CNT), the aluminum activation clay tool (AACT), and the gamma-ray spectrometry tool (GST). (GLT, NGT, CNT, AACT, and GST are trademarks of Schlumberger; Fig. 2.) The natural gamma-ray tool is located at the top of the tool string so that it can measure the naturally occurring radionuclides, thorium (Th), uranium (U), and potassium (K), before the formation is irradiated by the nuclear sources contained in the lower tools. The CNT, located below 


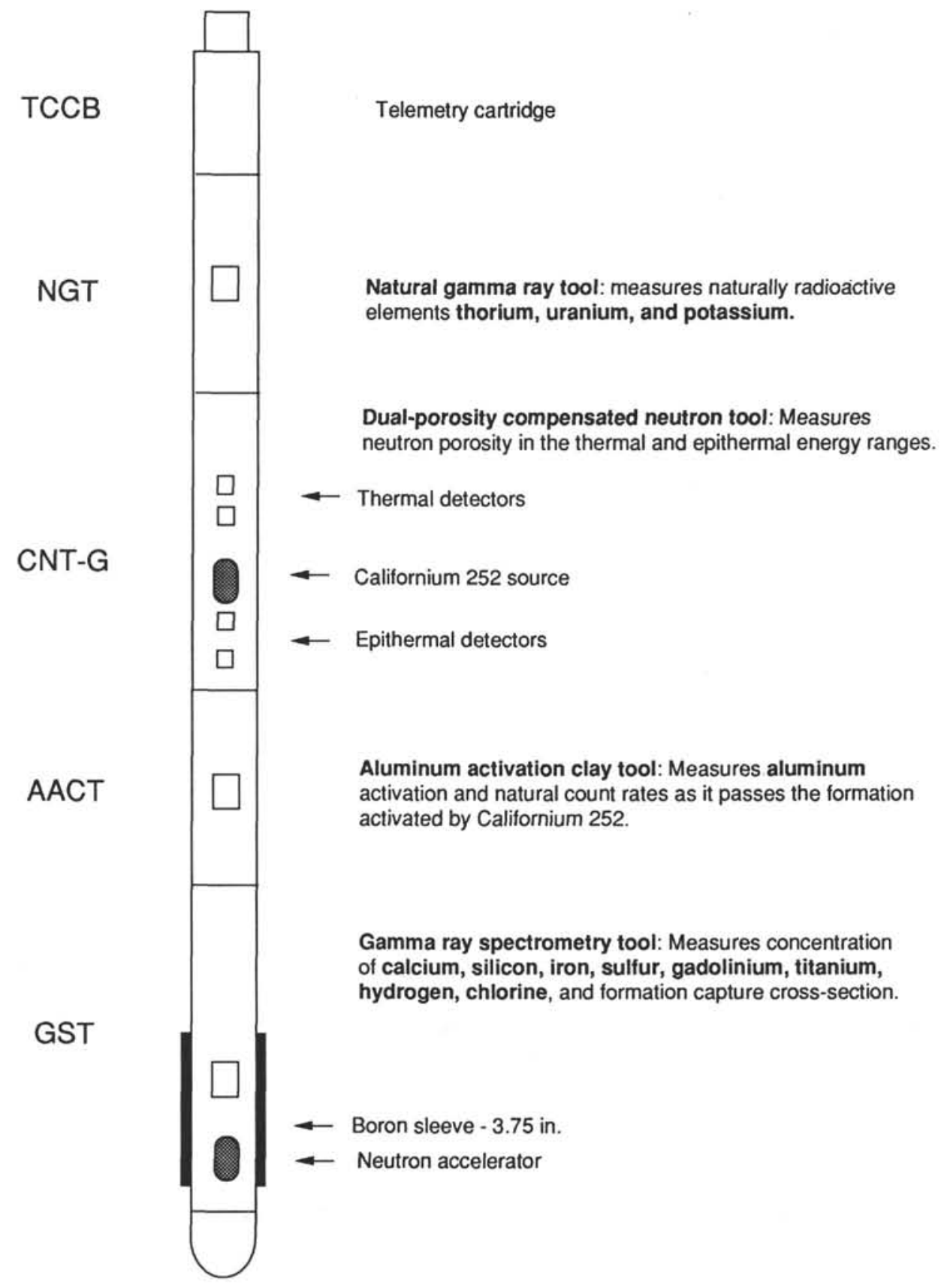

Figure 2. Schematic drawing of the Schlumberger geochemical logging tool string used in the Ocean Drilling Program.

the NGT, carries a low-energy californium-252 $\left({ }^{252} \mathrm{Cf}\right)$ neutron source to activate the $\mathrm{Al}$ atoms in the formation. The AACT, a modified NGT, is located below the ${ }^{252} \mathrm{Cf}$ source to measure the activated gamma rays in the formation. By combining the AACT measurement with the previous NGT measurement, background radiation is subtracted out and a reading of formation Al is obtained (Scott and Smith, 1973). The gamma-ray spectrometry tool, at the base of the string, carries a pulsed neutron generator to induce prompt-capture gamma-ray reactions in the borehole and formation and an $\mathrm{NaI}(\mathrm{Tl})$ scintillation detector to measure the energy spectrum of gamma rays generated by the neutron capture reactions. Because each of the elements in the formation is characterized by a unique spectral signature, it is possible to derive the contribution (or yield) of each of the major elements silicon $(\mathrm{Si})$, iron $(\mathrm{Fe})$, calcium $(\mathrm{Ca})$, titanium $(\mathrm{Ti})$, sulfur $(\mathrm{S})$, gadolin- ium (Gd), and potassium (K) from the measured spectrum and, in turn, to estimate the relative abundance of each in the formation when combined with the elemental concentrations from the NGT and AACT. The GST also measures the hydrogen $(\mathrm{H})$ and chlorine $(\mathrm{Cl})$ in the borehole and formation, but these elements are not used for determining rock geochemistry.

The only major rock-forming elements not measured by the geochemical tool string are magnesium $(\mathrm{Mg})$ and sodium $(\mathrm{Na})$; the neutron-capture cross sections of these elements are too small relative to their typical abundances in the formation for the tool string to detect them. A rough estimate of $\mathrm{Mg}+\mathrm{Na}$ can be made by using the photoelectric factor (PEF), measured by the lithodensity tool. This measured PEF is compared with a calculated PEF (a summation of the PEF from all of the measured elements). The separation between 
the measured and calculated PEF is, in theory, attributable to any element left over in the formation (i.e., $\mathrm{Mg}$ and $\mathrm{Na}$ ). Further explanation of this technique is found in Hertzog et al. (1989). This calculation was attempted, but it yielded scattered $\mathrm{Mg}+\mathrm{Na}$ spikes along a straight zero curve; the spikes were determined to be noise. The inclusion of this unreliable $\mathrm{Mg}+\mathrm{Na}$ curve in the normalization with the other elements would have induced noise into all the other elements, so it was left out.

\section{DATA REDUCTION}

The well-log data from the Schlumberger tools are transmitted digitally up a wireline and are recorded and processed on the JOIDES Resolution in the Schlumberger Cyber Service Unit (CSU). The results from the CSU are made available as "field logs" for initial, shipboard interpretation. Subsequent reprocessing is necessary to correct the data for the effects of fluids added to the well, logging speed, and drill-pipe interference. Processing of the spectrometry data is required to transform the relative elemental yields into oxide weight fractions.

The processing is performed with a set of Schlumberger log-interpretation programs modified for ODP hole conditions and lithologies. The steps are summarized below:

\section{Reconstruction of Relative Elemental Yields from Recorded Spectral Data}

This first processing step uses a weighted, least-squares method to compare the measured spectra from the gamma-ray spectrometry tool with a series of standard spectra to determine the relative contribution (or yield) of each element. Whereas six elemental standards ( $\mathrm{Si}, \mathrm{Fe}, \mathrm{Ca}, \mathrm{S}, \mathrm{Cl}$, and $\mathrm{H}$ ) are used to produce the shipboard yields, three additional standards ( $\mathrm{Ti}, \mathrm{Gd}$, and $\mathrm{K}$ ) can be included in the shore-based processing to improve the fit of the spectral standards to the measured spectra (Grau and Schweitzer, 1989). These additional three standards cannot be included during the shipboard processing because of limited processing power. Although $\mathrm{Ti}, \mathrm{Gd}$, and $\mathrm{K}$ often appear in the formation in very low concentrations, they can make a large contribution to the measured spectra because they have large neutron-capture cross sections. For example, the capture cross section of $\mathrm{Gd}$ is 49,000 barns, whereas that of $\mathrm{Si}$ is 0.16 barns (Hertzog et al., 1989). Therefore, including Gd is necessary when calculating the best fit of the standard spectra to the measured spectrum.

The best-fit analysis was attempted here at the Borehole Research Group; however, the results clearly indicated that the tool was malfunctioning throughout the logging operations of this leg. The data were sent to the Schlumberger-Doll Research Center in Ridgefield, Connecticut, to determine whether the data could be salvaged. Jim Grau and Roy Dove, of Schlumberger-Doll found that the gains and offsets of the spectra were out of range and, using their in-house software, recalibrated them. The newly computed gains and offsets were incorporated into the processing here. The spectral analysis was performed for Holes $805 \mathrm{C}$ and $806 \mathrm{~B}$ using the spectral standards for $\mathrm{Si}, \mathrm{Ca}, \mathrm{Gd}, \mathrm{H}$, and $\mathrm{Cl}$ only. The spectral standards for $\mathrm{K}, \mathrm{S}, \mathrm{Ti}$, and $\mathrm{Fe}$ were not used, because these four elements existed in concentrations below the resolution of the tool, and including them would have significantly increased the noise level of all the other yields. A straight, seven-point $(3.5 \mathrm{ft}, 1.066 \mathrm{~m})$ smoothing filter was applied to all the yields in both holes to reduce the noise in the data.

\section{Depth Shifting}

Geochemical processing involves the integration of data from the different tool strings; consequently, it is important that all the data are depth correlated to one reference logging run. The NGT, run on each of the logging tool strings, provides a spectral gamma-ray curve with which to correlate each of the logging runs. A reference run is chosen on the basis of least cable tension (the logging run with the least amount of cable sticking) and highest cable speed (tools run at faster speeds are less likely to stick and are less susceptible to data degradation caused by ship heave). The depth-shifting procedure involves picking a number of reference points based on similar log character and then invoking a program that stretches and squeezes the matching logging run to fit the reference logging run.

The geophysical run was used as a reference run in Hole $805 \mathrm{C}$. As well as could be determined with the low character in the total gamma-ray curves, the two logging runs were found to be on depth in Hole 806B.

\section{Calculation of Total Radioactivity and Th, U, and $K$ Concentrations}

The third processing routine calculates the total natural gamma radiation in the formation as well as concentrations of $\mathrm{Th}, \mathrm{U}$, and $\mathrm{K}$, using the counts in five spectral windows from the natural gamma-ray tool (Lock and Hoyer, 1971). This routine resembles shipboard processing, except that corrections for hole-size changes are made in the shore-based processing of these curves. Kalman filtering (Ruckebusch, 1983 ) is used in the CSU processing at sea to minimize the statistical uncertainties in the logs, which can otherwise create erroneous negative values and anti-correlations (especially between Th and $\mathrm{U}$ ). An alpha filter, recently introduced and recommended by Schlumberger for shore-based processing, strongly filters the raw spectral curves but keeps the total gamma-ray curve unsmoothed before calculating out the Th, U, and K (C. Flaum, pers. comm., 1988). The outputs of this program are $\mathrm{K}$ (wet wt\%), $\mathrm{U}$ (ppm), and $\mathrm{Th}$ (ppm), as well as total and computed gamma-ray (total gamma ray minus $\mathrm{U}$ contribution).

\section{Calculation of Al Concentration}

The fourth processing routine calculates an $\mathrm{Al}$ curve using four energy windows, and concurrently corrects for natural radioactivity, borehole-fluid neutron-capture cross section, formation neutroncapture cross section, formation slowing-down length, and borehole size. Porosity and density logs are needed in this routine to convert the wet-weight percentages of $\mathrm{K}$ and $\mathrm{Al}$ curves to dry-weight percentages. Because the density logs in each of the three holes compared well with shipboard core measurements, and because no porosity log was recorded, a porosity curve was derived from the density log using the equation,

$$
P H I T=(R H O M-R H O B) /(R H O M-R H O F),
$$

where $P H I T=$ percentage porosity, $R H O M=$ matrix density $($ a constant value of $2.69 \mathrm{~g} / \mathrm{cm}^{3}$ was used), $R H O B=$ bulk density from the $\log$ in $\mathrm{g} / \mathrm{cm}^{3}$, and $R H O F=$ density of fluid $=1.05 \mathrm{~g} / \mathrm{cm}^{3}$.

A correction was also made for $\mathrm{Si}$ interference with $\mathrm{Al}$; the ${ }^{252} \mathrm{Cf}$ source activates the $\mathrm{Si}$, producing the aluminum isotope ${ }^{28} \mathrm{Al}$ (Hertzog et al., 1989). The program uses the $\mathrm{Si}$ yield from the gamma-ray spectrometry tool to determine the $\mathrm{Si}$ background correction. The program outputs dry-weight percentages of $\mathrm{Al}$ and $\mathrm{K}$, which are used in the calculation and normalization of the remaining elements.

\section{Normalization of Elemental Yields from the GST to Calculate the Elemental Weight Fractions}

This routine combines the dry-weight percentages of $\mathrm{Al}$ and $\mathrm{K}$ with the reconstructed yields to obtain dry-weight percentages of the GST elements using the relationship,

$$
W t_{i}=F Y_{i} / S_{i},
$$


where $W t_{i}=$ absolute elemental concentration, $F=$ normalization factor, $Y_{i}=$ relative elemental yield, and $S_{i}=$ tool spectral sensitivity factor.

The normalization factor, $F$, is a calibration factor determined at each depth from a closure argument to account for the number of neutrons captured by a specific concentration of rock elements. Because the sum of oxides in a rock is $100 \%, F$ is given by

$$
F\left(\sum_{i} X_{i} Y_{i} / S_{i}\right)+X_{K} W t_{K}+X_{A l} W t_{A l}=100
$$

where $X_{i}=$ dry wt $\%$ of oxide or carbonate $\div$ dry wt $\%$ of element $i, X_{K}$ $=$ dry $w t \%$ of oxide of element $\mathrm{K} \div$ dry $w \mathrm{t} \%$ of $\mathrm{K}, W t_{K}=$ dry $\mathrm{wt} \%$ of $\mathrm{K}, X_{A l}=$ dry $w \mathrm{t} \%$ of oxide of element $\mathrm{Al} \div$ dry $\mathrm{wt} \%$ of $\mathrm{Al}$, and $W t_{A I}=$ dry wt $\%$ of Al. The sensitivity factor, $S_{i}$, is a tool constant measured in the laboratory, which depends on the capture cross section, gammaray production, and detection probabilities of each element measured by the GST (Hertzog et al., 1989).

The value, $X_{i}$, accounts for the $\mathrm{C}$ and $\mathrm{O}$ associated with each element. Table 1 lists the oxide factors used in this calculation. The measured elements associate with $\mathrm{C}$ and $\mathrm{O}$ in a constant ratio in these lithologies, except for $\mathrm{Ca}$ and $\mathrm{Fe}$. $\mathrm{Ca}$ associates with $\mathrm{C}$ and $\mathrm{O}$ in one of two ways: $\mathrm{CaCO}_{3}$ or $\mathrm{CaO}$, and $\mathrm{Fe}$ associates as either $\mathrm{Fe}_{2} \mathrm{O}_{3}$ or $\mathrm{FeO}$; therefore, a 50:50 ratio of the two is assumed (Table 1). To convert the measured yields to elements/oxides, a dominant form of $\mathrm{Ca}$ must be assumed. The assumption is based both on the dominant lithology described in the cores and on the log signatures. In both Holes $805 \mathrm{C}$ and $806 \mathrm{~B}, \mathrm{CaCO}_{3}$ was assumed.

\section{Calculation of Oxide Percentages}

The sixth and final routine simply multiplies the percentage of each element by its associated oxide factor, using the same oxide factors as were used in the previous step (Table 1).

\section{COMPARISON OF GEOCHEMICAL LOGS TO CORE}

\section{Site 805}

The sediments at Site 805 were grouped into one lithologic unit (Unit I; Shipboard Scientific Party, 1991a), composed of chalk and ooze. The degree of consolidation, however, divides the unit into two subunits: Subunit IA, primarily composed of ooze, and Subunit IB, primarily composed of chalk. The shipboard logs distinguished four logging units based on geophysical-log characteristics (Shipboard Scientific Party, 1991a, "Logging" section).

The processed natural gamma-ray curves at Hole $805 \mathrm{C}$, shown in Figure 3, are compared to the lithostratigraphic units described from the core (Shipboard Scientific Party, 1991a). The natural gamma-ray curves come from the GLT string below $567 \mathrm{mbsf}$ and from the geophysical tool string above this depth. Subunit IA is seen to be slightly higher in total gamma-ray content (SGR) than Subunit IB, because of the elevated $U$ in this upper subunit.

Figure 4 displays the oxide weight fractions estimated from the logs at Hole $805 \mathrm{C}$, along with calculated statistical uncertainties of each element (Grau et al., 1990; Schweitzer et al., 1988). This error is strongly related to the normalization factor, which is calculated at each depth (Eq. 3). The normalization factor is displayed along with oxide measurements to the right. A lower normalization factor represents better counting statistics and higher quality data. Available core measurements of $\mathrm{CaCO}_{3}$ are displayed as solid circles for comparison. The logs show a general overall agreement with the cores, though their values are slightly lower than those from core. This may be the result of the tool problems experienced at these holes or of spectral interference from $\mathrm{Cl}$. The resemblance between the spectral signatures of $\mathrm{Cl}$ and $\mathrm{Ca}$ causes interference in high-porosity sediments, where the $\mathrm{Cl}$ yield dominates the total spectra.
Table 1. Oxide factors used in normalizing elements to $100 \%$ and converting elements to oxides.

\begin{tabular}{ccc}
\hline Element & Oxide/carbonate & $\begin{array}{c}\text { Conversion } \\
\text { factor }\end{array}$ \\
\hline $\mathrm{Si}$ & $\mathrm{SiO}_{2}$ & 2.139 \\
$\mathrm{Ca}$ & $\mathrm{CaO}$ & 1.399 \\
$\mathrm{Fe}$ & $\mathrm{FeO}^{*}($ total $\mathrm{Fe})$ & 1.358 \\
$\mathrm{~K}$ & $\mathrm{~K}_{2} \mathrm{O}$ & 1.205 \\
$\mathrm{Ti}$ & $\mathrm{TiO}_{2}$ & 1.668 \\
$\mathrm{Al}$ & $\mathrm{Al}_{2} \mathrm{O}_{3}$ & 1.899 \\
\hline
\end{tabular}

\section{Site 806}

As with the sediments at Site 805 , the sediments at Site 806 are grouped into one lithostratigraphic unit, which is divided into two subunits based on the degree of lithification: Subunit IA, composed of ooze, and Subunit IB, composed of chalk. The shipboard logs distinguished three logging units based on the geophysical-log characteristics (Shipboard Scientific Party, 1991b, "Logging" section).

The processed natural gamma-ray logs from Hole 806B (Fig. 5) come from the geophysical tool string in the interval from the top of the hole to $417 \mathrm{mbsf}$, from the GLT in the interval from 417 to 431 mbsf, and from the geophysical tool string in the interval from 431 to $668 \mathrm{mbsf}$, where the NGT measurements were activated by the ${ }^{252} \mathrm{Cf}$ source on the GLT and so could not be used. The logs of Subunit IA have a higher overall gamma-ray value primarily because of their elevated $\mathrm{U}$ content. The $\mathrm{U}$ and gamma-ray values decrease downsection within this subunit. Subunit IB displays a very low, uniform natural gamma-ray content.

The oxide-weight fractions for Hole $806 \mathrm{~B}$ are shown along with uncertainties in Figure 6. Carbonate analyses are displayed as solid circles for comparison. The carbonate logs are in agreement with the core measurements; however, they are slightly low in the upper zone, as was seen in Hole $805 \mathrm{C}$. The fact that the logs are lower in the upper part of the hole, where porosities are higher, supports the likelihood that there is interference between the $\mathrm{Cl}$ and $\mathrm{Ca}$ spectral yields.

High-resolution sampling was performed for Hole 806B in an attempt to test the resolution of the carbonate measurement made by the geochemical tool. These samples were taken over the interval from 570 to $600 \mathrm{mbsf}$ at $10-\mathrm{cm}$ intervals (Appendix). An enlarged section of the geochemical log is compared with these core measurements in Figure 7. Although a similar mean value is seen between the two data sets, the variation is much higher in the log carbonate values than in the high-resolution core carbonate values, indicating a higher noise level in the log measurements. However, because the GST tool was malfunctioning throughout the logging, we cannot fairly use this as a test of the GST's accuracy. We must also consider that, because the detection threshold of Ca for the GST has been found to be $2 \%$ (Jarrard and Lyle, 1991), and because the standard deviation of the high-resolution samples was 1.38 , it is possible that, even if the tool had been working properly, it would not have been able to detect the small variations in carbonate found on the Ontong Java Plateau.

\section{SUMMARY AND CONCLUSIONS}

The reprocessing of natural gamma-ray logs improves the measurements obtained in the field by incorporating hole-size corrections and better calibrations of $\mathrm{Th}, \mathrm{U}$, and $\mathrm{K}$.

Geochemical logs were converted to elemental and oxide measurements and were compared to carbonate core measurements. The GST was not working properly throughout the logging operations of this leg. Extreme efforts were made to correct for the tool problems; however, the data are still less than ideal. Core-log comparisons indicate that the resulting carbonate log values fall within the right 

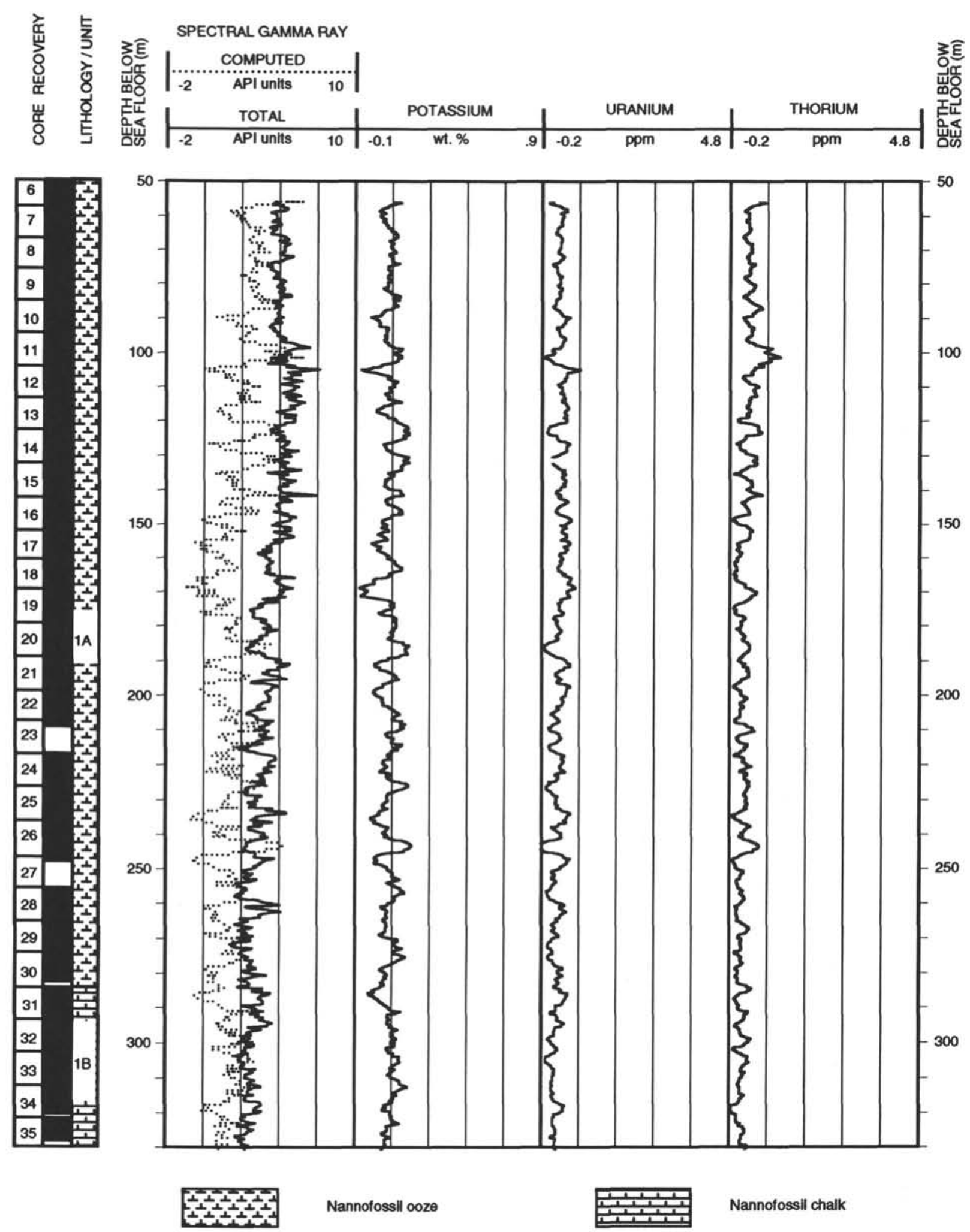

Figure 3. Processed natural gamma-ray data, Hole $805 \mathrm{C}$. The symbols used in the lithologic legend are common to all of the following figures. 

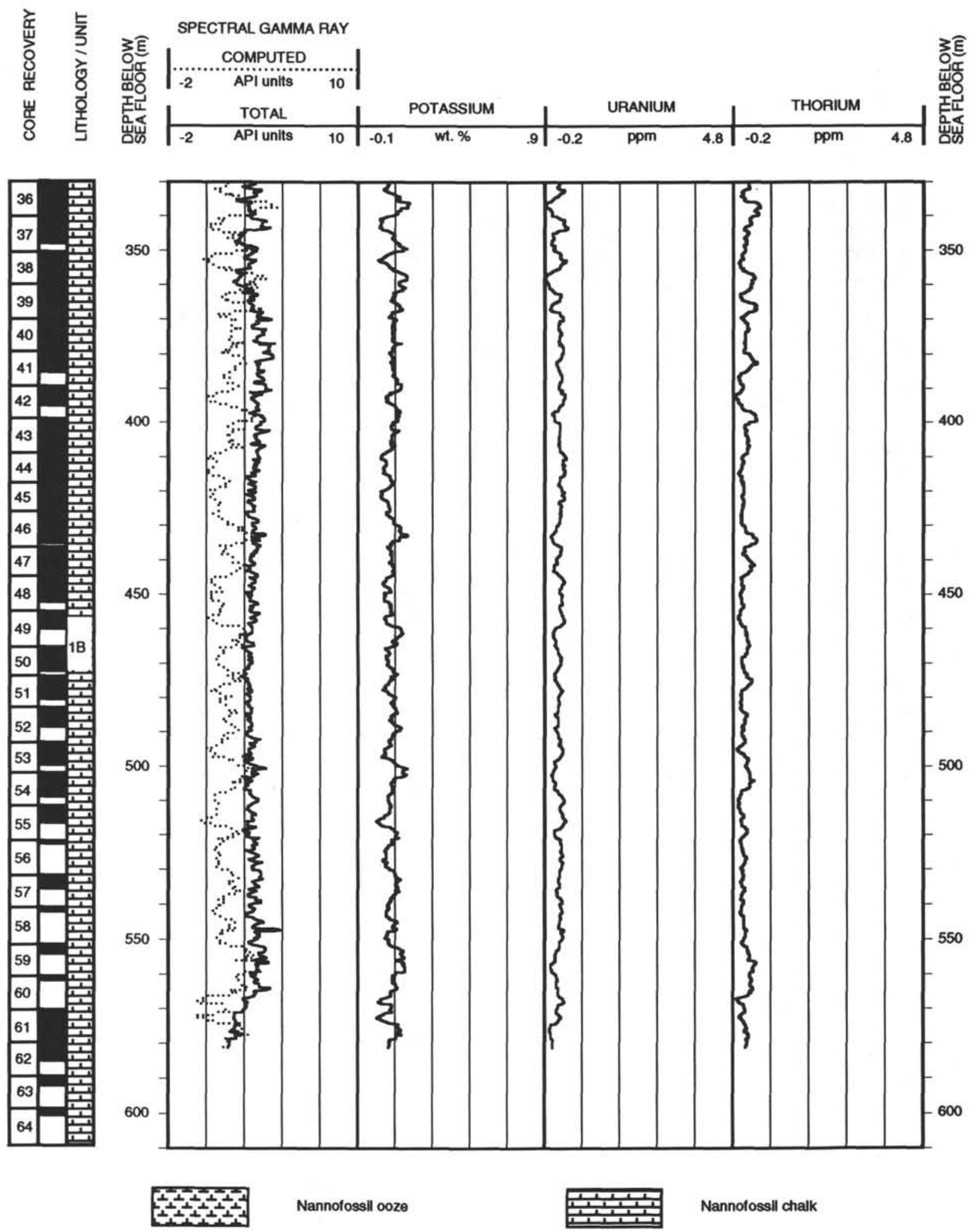

Figure 3 (continued). 

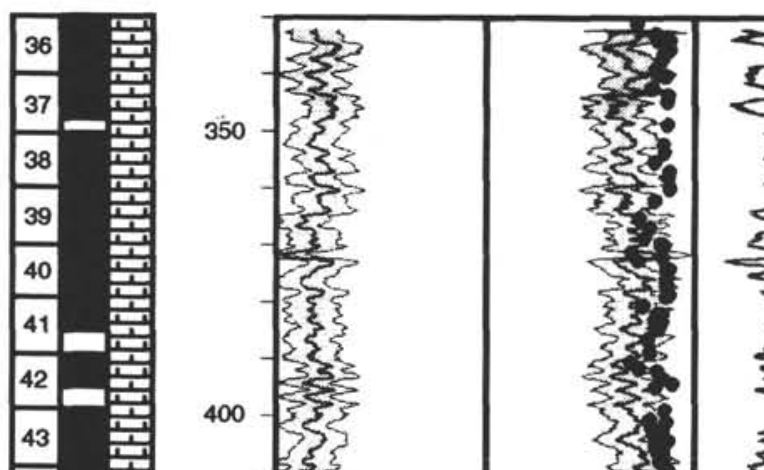

400
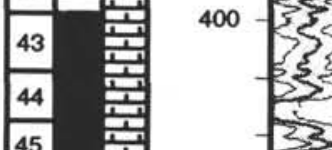

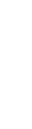

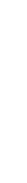

450

है।

$48 \quad \mathrm{C}$

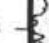

$49-18$

उद

50

51

52

53

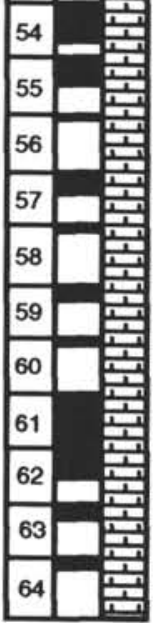

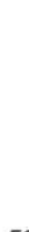

500
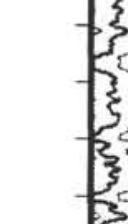

है

550

दर

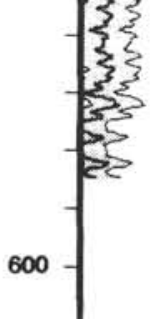

\begin{tabular}{c|cc}
$\mathrm{CaCO}_{3}$ & \multicolumn{1}{|c}{$\mathrm{Al}_{2} \mathrm{O}$} \\
\hline$\% \quad 100$ & 0 & $\%$
\end{tabular}

Normalization

고트 Factor

1000 b\% 
range of values in the lower part of the holes; however, log values are low in the upper logged part, which was probably caused by interference between the spectral signatures of $\mathrm{Cl}$ and $\mathrm{Ca}$.

\section{ACKNOWLEDGMENTS}

The first author would like to thank Jim Grau and Roy Dove at the Schlumberger-Doll Research Center for all their efforts in attempts to correct the data for tool malfunction. We would also like to thank James Bristow for his critical reviews of the manuscript and Ali Rodell for his work on the carbonate analyses.

\section{REFERENCES}

Grau, J.A., and Schweitzer, J.S., 1989. Elemental concentrations from thermal neutron capture gamma-ray spectra in geological formations. Nucl. Geophys., 3:1-9.

Grau, J.A., Schweitzer, J.S., and Hertzog, R.C., 1990. Statistical uncertainties of elemental concentrations extracted from neutron-induced gamma-ray measurements. IEEE Trans. Nucl. Sci., 37:2175-2178.

Hertzog, R., Colson, L., Seeman, B., O'Brien, M., Scott, H., McKeon, D., Wraight, J., Grau, J., Ellis, D., Schweitzer, J., and Herron, M., 1989. Geochemical logging with spectrometry tools. SPE Formation Eval., 4:153-162.

Jarrard, R.D., and Lyle, M., 1991. High-resolution geochemical variations at Sites 723,728 , and 731: a comparison of X-ray fluorescence and geo- chemical logs. In Prell, W.L., Niitsuma, N., et al., Proc. ODP, Sci. Results, 117: College Station, TX (Ocean Drilling Program), 473-498.

Kroenke, L.W., Jouannic, C., and Woodward, P., 1983. Bathymetry of the Southwest Pacific, Chart I. The Geophysical Atlas of the Southwest Pacific, Mercator Projection (Scale 1:6,442,192 at 0 degrees): Suva, Fiji. U.N. Econ. Soc. Comm. Asia Pac/CCOP/SOPAC.

Lock, G.A., and Hoyer, W.A., 1971. Natural gamma-ray spectral logging. Log Anal., 12:3-9.

Ruckebusch, G., 1983. A Kalman filtering approach to natural gamma ray spectroscopy in well logging. IEEE Trans., AC-28:372-380.

Schweitzer, J.S., Grau, J.A., and Hertzog, R.C., 1988. Precision and accuracy of short-lived activation measurements for in situ geological analyses. $J$. Trace Microprobe Tech., 6:437-451.

Scott, H.D., and Smith, M.P., 1973. The aluminum activation log. Log Anal., $14: 3-12$.

Shipboard Scientific Party, 1991a. Site 805. In Kroenke, L.W., Berger, W.H., Janecek, T.R., et al., Proc. ODP, Init. Repts., 130: College Station, TX (Ocean Drilling Program), 223-290.

, 1991b. Site 806. In Kroenke, L.W., Berger, W.H., Janecek, T.R., et al., Proc. ODP, Init. Repts., 130: College Station, TX (Ocean Drilling Program), 291-367.

Date of initial receipt: 22 October 1991

Date of acceptance: 17 May 1992

Ms 130B-056 

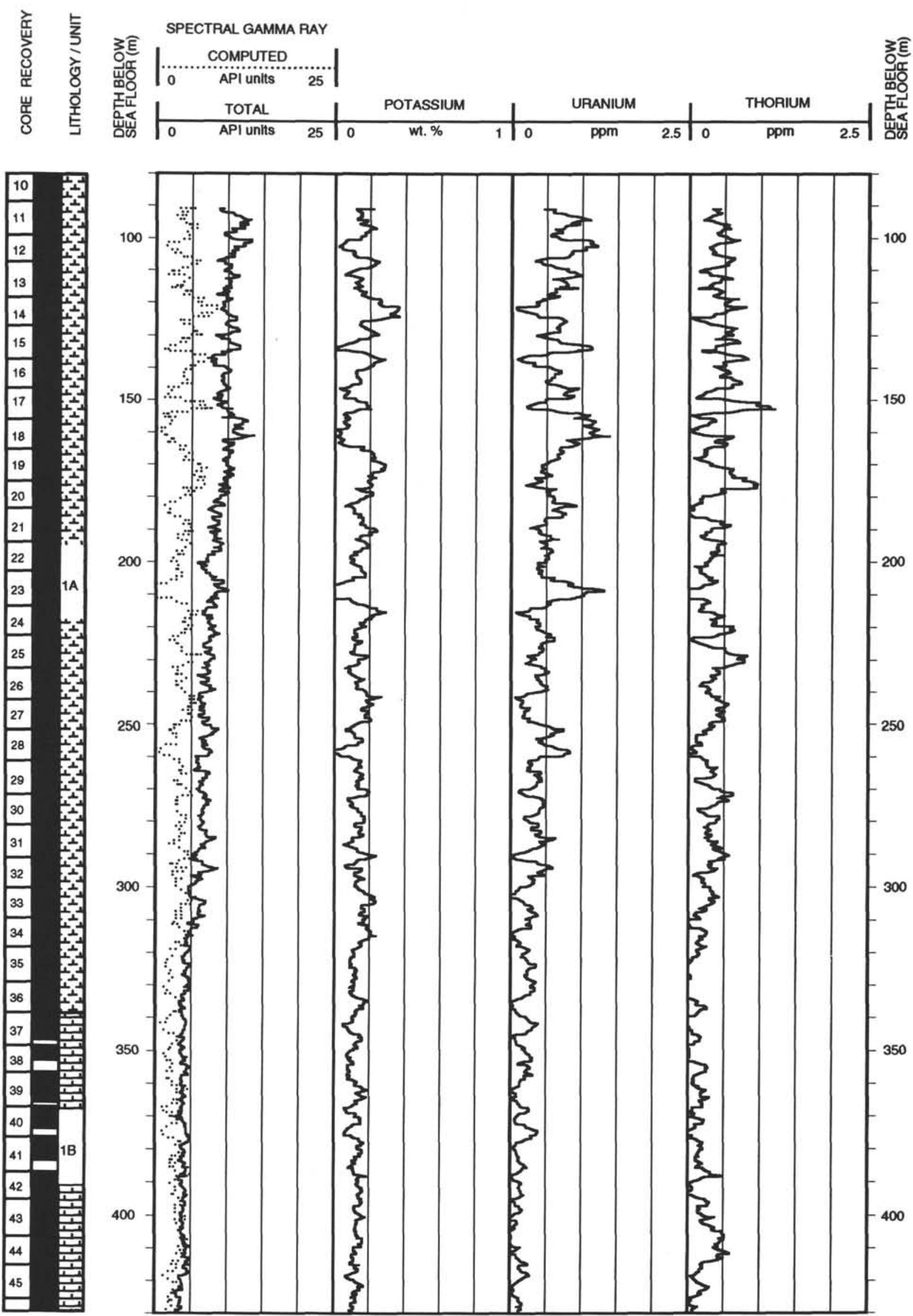

Figure 5. Processed natural gamma-ray data, Hole 806B. 

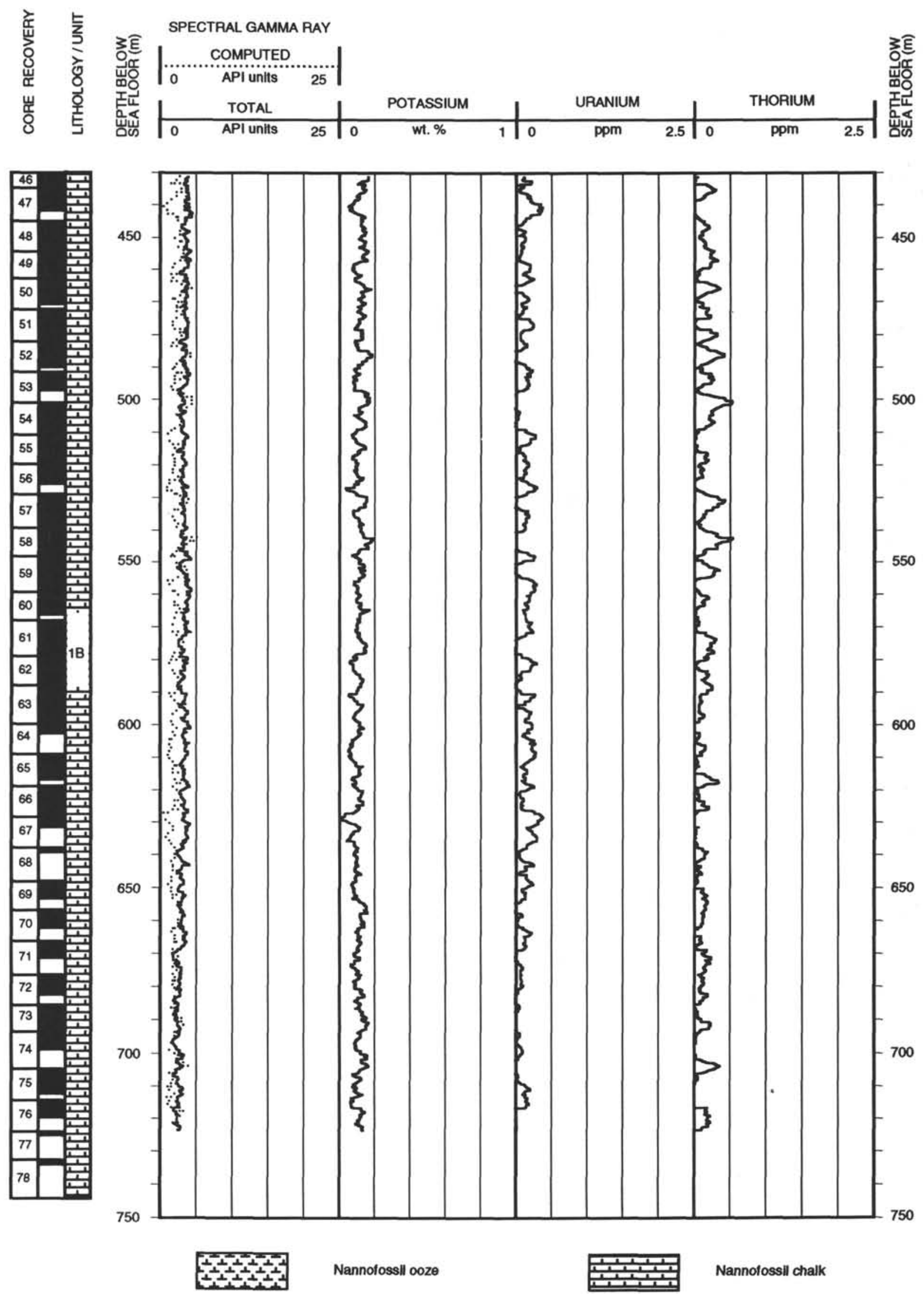

Figure 5 (continued). 
立

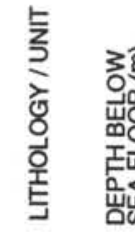
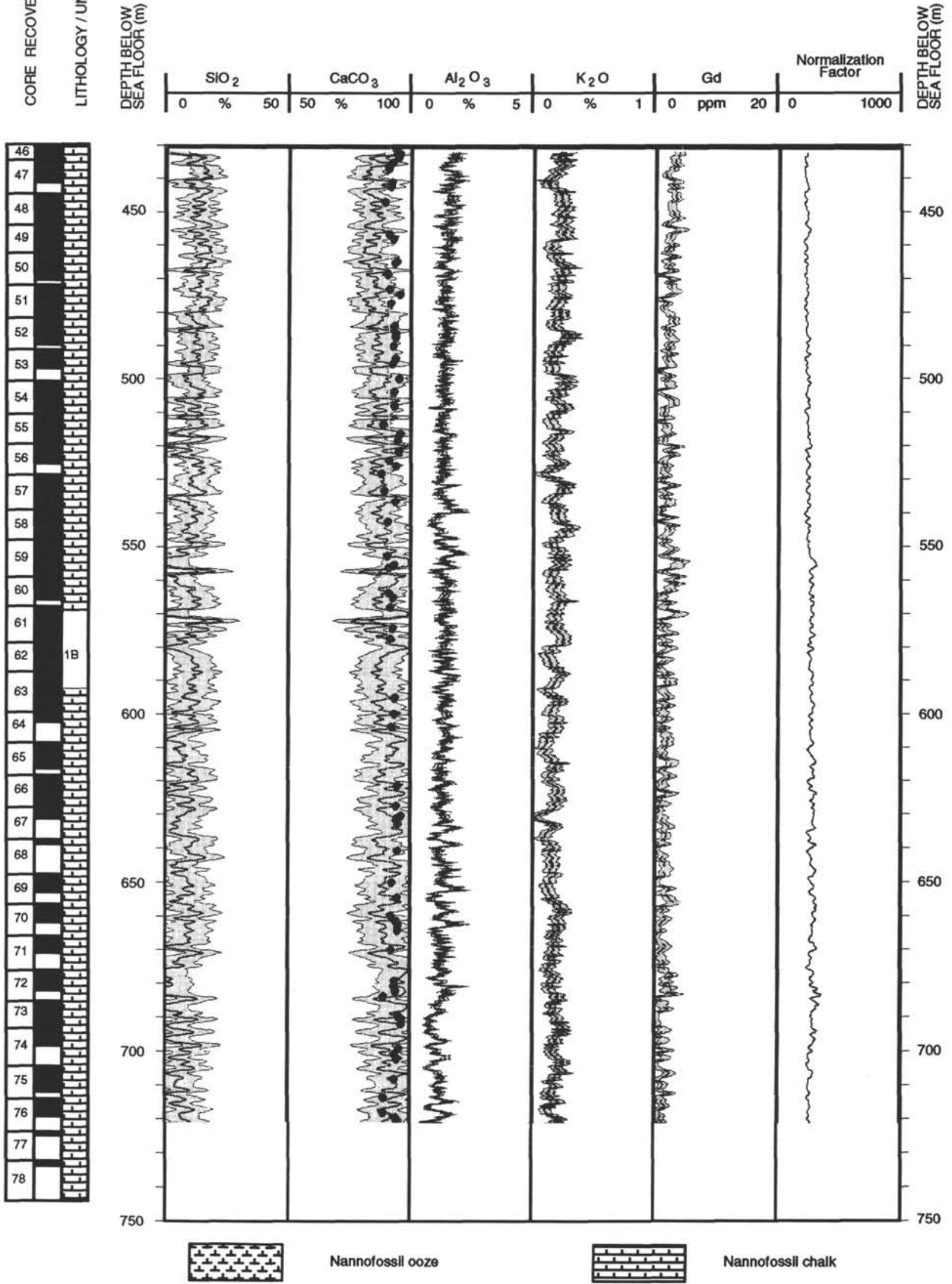

Figure 6. Calcium carbonate and major oxide-weight fractions from geochemical logs run in Hole 806B compared with carbonate core measurements, represented by solid circles (Shipboard Scientific Party, 1991b). 


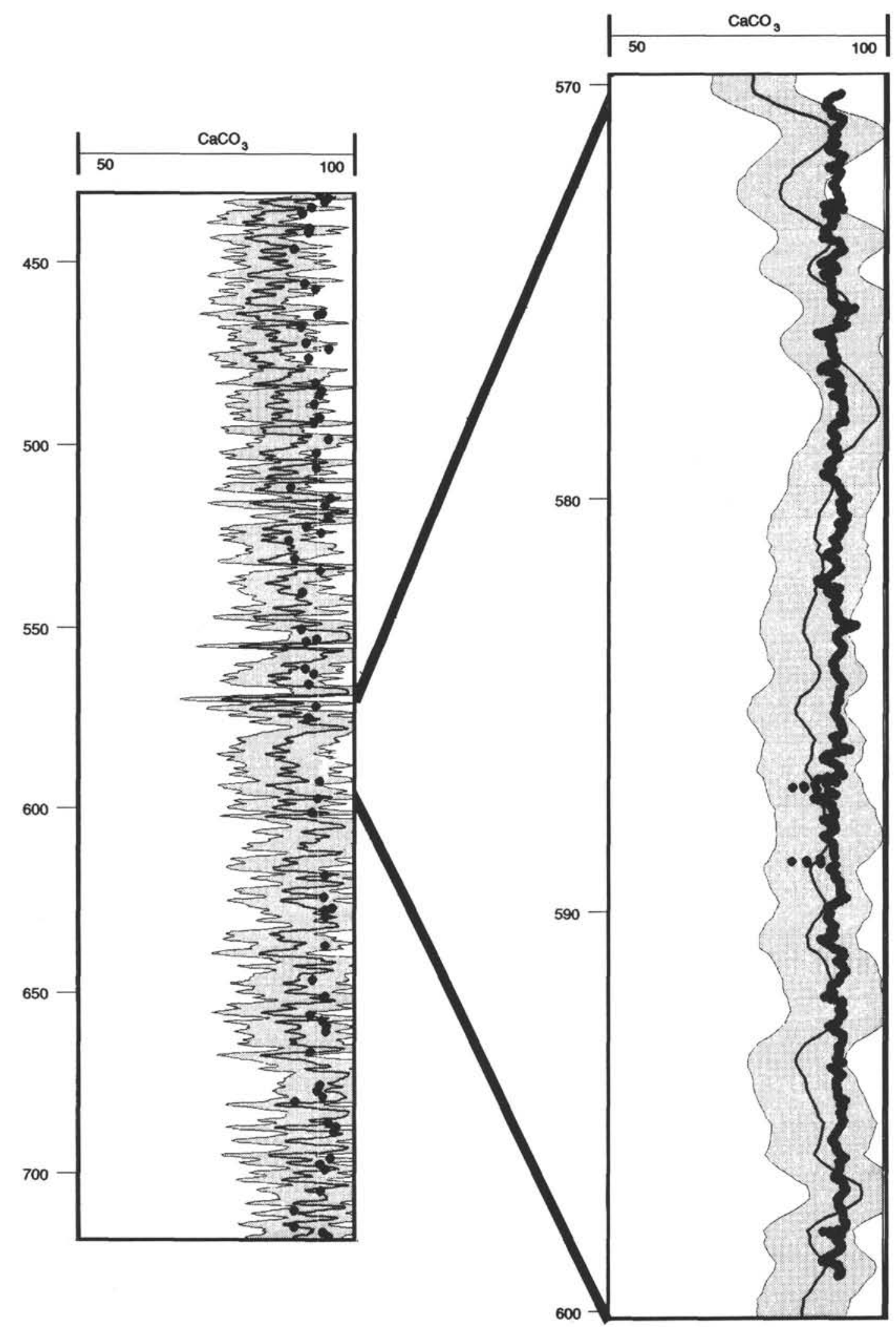

Figure 7. Blowup of high-resolution carbonate sampling compared with log carbonate measurements in Hole 806B. 
APPENDIX

High-resolution Samples, Hole 806B

\begin{tabular}{|c|c|c|c|c|c|c|c|c|c|c|c|}
\hline $\begin{array}{l}\text { Core, section, } \\
\text { interval }(\mathrm{cm})\end{array}$ & $\begin{array}{l}\text { Depth } \\
\text { (mbsf) }\end{array}$ & $\begin{array}{c}\mathrm{CaCO}_{3} \\
(\%)\end{array}$ & $\begin{array}{l}\text { Core, section, } \\
\text { interval }(\mathrm{cm})\end{array}$ & $\begin{array}{l}\text { Depth } \\
\text { (mbsf) }\end{array}$ & $\begin{array}{c}\mathrm{CaCO}_{3} \\
(\%)\end{array}$ & $\begin{array}{l}\text { Core, section, } \\
\text { interval }(\mathrm{cm})\end{array}$ & $\begin{array}{l}\text { Depth } \\
\text { (mbsf) }\end{array}$ & $\begin{array}{c}\mathrm{CaCO}_{3} \\
(\%)\end{array}$ & $\begin{array}{l}\text { Core, section, } \\
\text { interval }(\mathrm{cm})\end{array}$ & $\begin{array}{l}\text { Depth } \\
\text { (mbsf) }\end{array}$ & $\begin{array}{c}\mathrm{CaCO}_{3} \\
(\%)\end{array}$ \\
\hline $130-806 \mathrm{~B}-$ & & & $61 X-5,125.5$ & 579.56 & 91.95 & $62 X-4,26.5$ & 586.77 & 91.89 & $63 X-2,75.5$ & 593.96 & 90.44 \\
\hline $62 X-1,5.5$ & 572.36 & 91.85 & $61 X-5,135.5$ & 579.66 & 90.43 & $62 X-4,38.5$ & 586.89 & 91.73 & $63 X-2,85.5$ & 594.06 & 90.25 \\
\hline $62 X-1,15.5$ & 572.46 & 89.94 & $61 X-5,145.5$ & 579.76 & 92.14 & $62 X-4,46.5$ & 586.97 & 91.39 & $63 \mathrm{X}-2,95.5$ & 594.16 & 90.65 \\
\hline $62 X-1,23.5$ & 572.54 & 89.44 & $61 X-6,5.5$ & 579.86 & 92.29 & $62 X-4,56.5$ & 587.07 & 91.69 & $63 \mathrm{X}-2,105.5$ & 594.26 & 89.08 \\
\hline $62 X-1,35.5$ & 572.66 & 89.14 & $61 X-6,15.5$ & 579.96 & 92.36 & $62 X-4,66.5$ & 587.17 & 91.12 & $63 X-2,115.5$ & 594.36 & 92.23 \\
\hline $62 X-1,45.5$ & 572.76 & 90.04 & $61 X-6,25.5$ & 580.06 & 92.36 & $62 \times-4,76.5$ & 587.27 & 91.17 & $63 X-2,125.5$ & 594.46 & 92.23 \\
\hline $62 X-1,55.5$ & 572.86 & 90.12 & $61 X-6,35.5$ & 580.16 & 91.82 & $62 X-4,86.5$ & 587.37 & 90.74 & $63 X-2,135.5$ & 594.56 & 91.75 \\
\hline $62 X-1,65.5$ & 572.96 & 92.20 & $61 X-6,45.5$ & 580.26 & 92.67 & $62 X-4,97.5$ & 587.48 & 91.29 & $63 X-2,145.5$ & 594.66 & 92.62 \\
\hline $62 X-1,75.5$ & 573.06 & 92.02 & $61 X-6,55.5$ & 580.36 & 90.86 & $62 X-4,104.5$ & 587.55 & 91.91 & $63 X-3,5.5$ & 594.76 & 91.84 \\
\hline $62 X-1,85.5$ & 573.16 & 91.27 & $61 X-6,65.5$ & 580.46 & 90.26 & $62 X-4,116.5$ & 587.67 & 92.10 & $63 X-3,17.5$ & 594.88 & 91.42 \\
\hline $62 X-1,95.5$ & 573.26 & 90.32 & $61 X-6,75.5$ & 580.56 & 90.21 & $62 X-4,126.5$ & 587.77 & 92.42 & $63 X-3,25.5$ & 594.96 & 89.87 \\
\hline $62 X-1,105.5$ & 573.36 & 91.10 & $61 X-6,85.5$ & 580.66 & 91.18 & $62 X-4,134.5$ & 587.85 & 92.33 & $63 X-3,35.5$ & 595.06 & 90.75 \\
\hline $62 X-1,115.5$ & 573.46 & 90.24 & $61 X-6,95.5$ & 580.76 & 90.88 & $62 X-4,146.5$ & 587.97 & 90.61 & $63 X-3,46.5$ & 595.17 & 92.37 \\
\hline $62 X-1,125.5$ & 573.56 & 91.13 & $61 X-6,105.5$ & 580.86 & 90.20 & $62 X-5,6.5$ & 588.07 & 91.26 & $63 X-3,55.5$ & 595.26 & 92.37 \\
\hline $62 X-1,135.5$ & 573.66 & 89.39 & $61 X-6,115.5$ & 580.96 & 91.28 & $62 X-5,16.5$ & 588.17 & 91.34 & $63 X-3,65.5$ & 595.36 & 92.32 \\
\hline $62 X-1,144.5$ & 573.75 & 90.10 & $61 X-6,125.5$ & 581.06 & 91.18 & $62 X-5,24.5$ & 588.25 & 93.54 & $63 X-3,77.5$ & 595.48 & 91.57 \\
\hline $61 X-2,5.5$ & 573.86 & 92.41 & $61 X-6,135.5$ & 581.16 & 91.54 & $62 X-5,36.5$ & 588.37 & 89.41 & $63 X-3,85.5$ & 595.56 & 91.92 \\
\hline $61 X-2,13.5$ & 573.94 & 91.68 & $61 X-6,145.5$ & 581.26 & 90.21 & $62 X-5,45.5$ & 588.46 & 88.70 & $63 X-3,94.5$ & 595.65 & 91.76 \\
\hline $61 X-2,24.5$ & 574.05 & 91.70 & $61 X-7,5.5$ & 581.36 & 89.39 & $62 X-5,56.5$ & 588.57 & 90.27 & $63 X-3,105.5$ & 595.76 & 91.34 \\
\hline $61 X-2,35.5$ & 574.16 & 89.76 & $61 X-7,15.5$ & 581.46 & 90.48 & $62 X-5,66.5$ & 588.67 & 91.67 & $63 X-3,115.5$ & 595.86 & 92.38 \\
\hline $61 X-2,45.5$ & 574.26 & 91.92 & $61 X-7,27.5$ & 581.58 & 88.64 & $62 X-5,76.5$ & 588.77 & 91.65 & $63 X-3,125.5$ & 595.96 & 90.32 \\
\hline $61 X-2,55.5$ & 574.36 & 91.41 & $61 X-7,35.5$ & 581.66 & 89.66 & $62 X-5,86.5$ & 588.87 & 92.45 & $63 X-3,135.5$ & 596.06 & 91.63 \\
\hline $61 X-2,65.5$ & 574.46 & 91.05 & $61 X-7,45.5$ & 581.76 & 91.08 & $62 X-5,94.5$ & 588.95 & 87.84 & $63 X-3,145.5$ & 596.16 & 92.23 \\
\hline $61 X-2,75.5$ & 574.56 & 90.25 & $61 \mathrm{X}-\mathrm{CC}, 5.5$ & 581.36 & 90.60 & $62 X-5,104.5$ & 589.05 & 91.21 & $63 X-4,5.5$ & 596.26 & 91.38 \\
\hline $61 X-2,86.5$ & 574.67 & 91.11 & $61 X-C C, 15.5$ & 581.46 & 90.44 & $62 X-5,116.5$ & 589.17 & 83.28 & $63 X-4,14.5$ & 596.35 & 91.31 \\
\hline $61 X-2,95.5$ & 574.76 & 91.19 & $61 \mathrm{X}-\mathrm{CC}, 25.5$ & 581.56 & 89.86 & $62 X-5,126.5$ & 589.27 & 89.87 & $63 X-4,24.5$ & 596.45 & 91.35 \\
\hline $61 X-2,105.5$ & 574.86 & 91.68 & $62 X-1,6.5$ & 582.07 & 92.25 & $62 X-5,136.5$ & 589.37 & 91.12 & $63 X-4,35.5$ & 596.56 & 91.48 \\
\hline $61 X-2,115.5$ & 574.96 & 91.94 & $62 X-1,14.5$ & 582.15 & 93.13 & $62 X-5,144.5$ & 589.45 & 87.21 & $63 X-4,45.5$ & 596.66 & 91.42 \\
\hline $61 X-2,124.5$ & 575.05 & 88.89 & $62 X-1,26.5$ & 582.27 & 91.65 & $62 X-6,9$ & 589.59 & 90.48 & $63 \mathrm{X}-4,55.5$ & 596.76 & 92.89 \\
\hline $61 X-2,135.5$ & 575.16 & 92.23 & $62 X-1,36.5$ & 582.37 & 92.15 & $62 X-6,17.5$ & 589.68 & 90.44 & $63 X-4,65.5$ & 596.86 & 92.03 \\
\hline $61 X-2,145.5$ & 575.26 & 89.14 & $62 X-1,46.5$ & 582.47 & 91.99 & $62 X-6,26.5$ & 589.77 & 90.83 & $63 \times-4,75.5$ & 596.96 & 92.58 \\
\hline $61 X-3,5.5$ & 575.36 & 90.99 & $62 X-1,56.5$ & 582.57 & 93.00 & $62 X-6,36.5$ & 589.87 & 90.83 & $63 X-4,85.5$ & 597.06 & 92.04 \\
\hline $61 X-3,16.5$ & 575.47 & 90.08 & $62 X-1,66.5$ & 582.67 & 92.93 & $62 X-6,46.5$ & 589.97 & 88.84 & $63 X-4,95.5$ & 597.16 & 92.15 \\
\hline $61 X-3,25.5$ & 575.56 & 90.44 & $62 X-1,76.5$ & 582.77 & 91.40 & $62 X-6,56.5$ & 590.07 & 90.69 & $63 \mathrm{X}-4,105.5$ & 597.26 & 92.67 \\
\hline $61 X-3,35.5$ & 575.66 & 88.81 & $62 X-1,85.5$ & 582.86 & 92.60 & $62 X-6,66.5$ & 590.17 & 90.98 & $63 X-5,4.5$ & 597.75 & 90.38 \\
\hline $61 X-3,45.5$ & 575.76 & 89.04 & $62 X-1,96.5$ & 582.97 & 91.90 & $62 X-6,76.5$ & 590.27 & 90.19 & $63 X-5,15.5$ & 597.86 & 91.34 \\
\hline $61 X-3,55.5$ & 575.86 & 88.55 & $62 X-1,106.5$ & 583.07 & 91.54 & $62 X-6,86.5$ & 590.37 & 88.89 & $63 X-5,25.5$ & 597.96 & 91.23 \\
\hline $61 X-3,65.5$ & 575.96 & 91.43 & $62 X-1,116.5$ & 583.17 & 90.57 & $62 X-6,94.5$ & 590.45 & 89.90 & $63 X-5,35.5$ & 598.06 & 91.89 \\
\hline $61 X-3,75.5$ & 576.06 & 91.87 & $62 X-1,126.5$ & 583.27 & 91.04 & $62 X-6,104.5$ & 590.55 & 90.59 & $63 X-5,45.5$ & 598.16 & 92.92 \\
\hline $61 X-3,85.5$ & 576.16 & 92.24 & $62 X-1,136.5$ & 583.37 & 91.45 & $62 X-6,116.5$ & 590.67 & 90.78 & $63 X-5,55.5$ & 598.26 & 91.74 \\
\hline $61 X-3,95.5$ & 576.26 & 90.83 & $62 X-1,146.5$ & 583.47 & 90.03 & $62 X-6,126.5$ & 590.77 & 90.67 & $63 X-5,65.5$ & 598.36 & 91.98 \\
\hline $61 X-3,105.5$ & 576.36 & 90.13 & $62 X-2,7.5$ & 583.58 & 89.27 & $62 X-6,136.5$ & 590.87 & 90.83 & $63 X-5,75.5$ & 598.46 & 91.87 \\
\hline $61 X-3,115.5$ & 576.46 & 88.25 & $62 X-2,16.5$ & 583.67 & 91.09 & $62 X-6,146.5$ & 590.97 & 83.21 & $63 X-5,85.5$ & 598.56 & 91.16 \\
\hline $61 X-3,125.5$ & 576.56 & 90.87 & $62 X-2,26.5$ & 583.77 & 91.15 & $62 X-7,6.5$ & 591.07 & 91.08 & $63 X-5,95.5$ & 598.66 & 91.06 \\
\hline $61 X-3,135.5$ & 576.66 & 91.25 & $62 X-2,36.5$ & 583.87 & 91.84 & $62 X-7,16.5$ & 591.17 & 89.97 & $63 X-5,105.5$ & 598.76 & 92.62 \\
\hline $61 X-3,144.5$ & 576.75 & 88.70 & $62 X-2,46.5$ & 583.97 & 90.77 & $62 X-7,26.5$ & 591.27 & 91.17 & $63 X-5,115.5$ & 598.86 & 92.78 \\
\hline $61 X-4,5.5$ & 576.86 & 90.18 & $62 X-2,56.5$ & 584.07 & 89.65 & $62 X-7,36.5$ & 591.37 & 90.87 & $63 X-5,126.5$ & 598.97 & 93.04 \\
\hline $61 X-4,18.5$ & 576.99 & 90.00 & $62 X-2,66.5$ & 584.17 & 87.77 & $62 X-7,45.5$ & 591.46 & 91.91 & $63 X-5,135.5$ & 599.06 & 92.34 \\
\hline $61 X-4,25.5$ & 577.06 & 90.19 & $62 X-2,76.5$ & 584.27 & 88.70 & $62 \mathrm{X}-\mathrm{CC}, 2.5$ & 591.03 & 90.78 & $63 X-5,145.5$ & 599.16 & 91.42 \\
\hline $61 X-4,35.5$ & 577.16 & 90.17 & $62 X-2,85.5$ & 584.36 & 91.71 & $62 \mathrm{X}-\mathrm{CC}, 16.5$ & 591.17 & 90.03 & $63 X-6,4.5$ & 599.25 & 91.70 \\
\hline $61 X-4,45.5$ & 577.26 & 90.53 & $62 X-2,95.5$ & 584.46 & 89.52 & $62 \mathrm{X}-\mathrm{CC}, 26.5$ & 591.27 & 87.08 & $63 X-6,15.5$ & 599.36 & 91.77 \\
\hline $61 X-4,55.5$ & 577.36 & 90.09 & $62 X-2,106.5$ & 584.57 & 91.51 & $63 \mathrm{X}-1,5.5$ & 591.76 & 91.96 & $63 X-6,25.5$ & 599.46 & 92.37 \\
\hline $61 X-4,65.5$ & 577.46 & 91.25 & $62 X-2,116.5$ & 584.67 & 91.49 & $63 X-1,15.5$ & 591.86 & 92.97 & $63 X-6,35.5$ & 599.56 & 92.58 \\
\hline $61 X-4,75.5$ & 577.56 & 94.31 & $62 X-2,126.5$ & 584.77 & 90.58 & $63 X-1,25.5$ & 591.96 & 91.48 & $63 X-6,45.5$ & 599.66 & 92.55 \\
\hline $61 X-4,85.5$ & 577.66 & 92.02 & $62 X-2,136.5$ & 584.87 & 90.95 & $63 X-1,35.5$ & 592.06 & 89.81 & $63 X-6,55.5$ & 599.76 & 93.01 \\
\hline $61 X-4,96.5$ & 577.77 & 91.64 & $62 X-2,146.5$ & 584.97 & 91.36 & $63 X-1,45.5$ & 592.16 & 89.44 & $63 \mathrm{X}-6,65.5$ & 599.86 & 92.76 \\
\hline $61 X-4,105.5$ & 577.86 & 91.23 & $62 X-3,7.7$ & 585.08 & 91.35 & $63 X-1,55.5$ & 592.26 & 90.14 & $63 X-6,75.5$ & 599.96 & 88.81 \\
\hline $61 X-4,115.5$ & 577.96 & 92.88 & $62 X-3,18.5$ & 585.19 & 92.76 & $63 X-1,65.5$ & 592.36 & 89.50 & $63 X-6,86.5$ & 600.07 & 92.18 \\
\hline $61 X-4,125.5$ & 578.06 & 90.64 & $62 X-3,24.5$ & 585.25 & 94.69 & $63 X-1,75.5$ & 592.46 & 90.24 & $63 \mathrm{X}-6,95.5$ & 600.16 & 91.26 \\
\hline $61 X-4,135.5$ & 578.16 & 87.73 & $62 X-3,36.5$ & 585.37 & 92.34 & $63 X-1,85.5$ & 592.56 & 91.01 & $63 \mathrm{X}-6,105.5$ & 600.26 & 92.10 \\
\hline $61 X-4,145.5$ & 578.26 & 89.95 & $62 X-3,46.5$ & 585.47 & 91.22 & $63 X-1,95.5$ & 592.66 & 90.10 & $63 X-6,115.5$ & 600.36 & 92.28 \\
\hline $61 X-5,5.5$ & 578.36 & 90.41 & $62 X-3,56.5$ & 585.57 & 91.21 & $63 X-1,105.5$ & 592.76 & 90.89 & $63 X-6,125.5$ & 600.46 & 91.24 \\
\hline $61 X-5,14.5$ & 578.45 & 89.82 & $62 X-3,66.5$ & 585.67 & 91.66 & $63 X-1,115.5$ & 592.86 & 88.39 & $63 X-6,135.5$ & 600.56 & 89.78 \\
\hline $61 X-5,25.5$ & 578.56 & 90.60 & $62 X-3,76.5$ & 585.77 & 92.46 & $63 \mathrm{X}-1,125.5$ & 592.96 & 89.54 & $63 X-6,146.5$ & 600.67 & 88.71 \\
\hline $61 X-5,35.5$ & 578.66 & 90.23 & $62 X-3,86.5$ & 585.87 & 92.21 & $63 X-1,135.5$ & 593.06 & 90.41 & $63 X-7,5.5$ & 600.76 & 91.70 \\
\hline $61 X-5,45.5$ & 578.76 & 91.21 & $62 X-3,96.5$ & 585.97 & 91.50 & $63 X-1,145.5$ & 593.16 & 92.38 & $63 X-7,15.5$ & 600.86 & 91.79 \\
\hline $61 X-5,55.5$ & 578.86 & 91.11 & $62 X-3,106.5$ & 586.07 & 91.00 & $63 X-2,5.5$ & 593.26 & 92.67 & $63 X-7,25.5$ & 600.96 & 92.19 \\
\hline $61 X-5,65.5$ & 578.96 & 88.77 & $62 X-3,116.5$ & 586.17 & 90.55 & $63 X-2,16.5$ & 593.37 & 91.34 & $63 X-7,35.5$ & 601.06 & 91.33 \\
\hline $61 X-5,75.5$ & 579.06 & 88.33 & $62 X-3,126.5$ & 586.27 & 90.90 & $63 X-2,25.5$ & 593.46 & 92.15 & $63 \mathrm{X}-\mathrm{CC}, 5.5$ & 600.76 & 92.75 \\
\hline $61 X-5,85.5$ & 579.16 & 91.16 & $62 X-3,136.5$ & 586.37 & 90.84 & $63 X-2,35.5$ & 593.56 & 92.76 & $63 X-C C, 16.5$ & 600.87 & 91.18 \\
\hline $61 X-5,95.5$ & 579.26 & 91.77 & $62 X-3,146.5$ & 586.47 & 91.40 & $63 X-2,45.5$ & 593.66 & 92.81 & $63 \mathrm{X}-\mathrm{CC}, 25.5$ & 600.96 & 92.07 \\
\hline $61 X-5,105.5$ & 579.36 & 89.81 & $62 X-4,6.5$ & 586.57 & 92.12 & $63 X-2,55.5$ & 593.76 & 91.98 & & & \\
\hline $61 X-5,115.5$ & 579.46 & 92.11 & $62 X-4,16.5$ & 586.67 & 92.73 & $63 X-2,65.5$ & 593.86 & 91.90 & & & \\
\hline
\end{tabular}

